\title{
ANALISIS PENDAPATAN DAN TINGKAT KEMISKINAN RUMAH TANGGA PETANI KAKAO DI KECAMATAN GEDONG TATAAN KABUPATEN PESAWARAN
}

\author{
(Analysis of Household Income and Poverty Level of Cocoa Farmers in Sungai Langka Village, \\ Gedong Tataan Subdistrict, Pesawaran Regency)
}

Sinta Okpratiwi, Dwi Haryono, Rabiatul Adawiyah

Jurusan Agribisnis, Fakultas Pertanian, Universitas Lampung, J1. Prof. Dr. Soemantri Brojonegoro No. 1 Bandar Lampung, 35145. Telp. 082279348465, e-mail : okpratiwi@ gmail.com

\begin{abstract}
The purposes of this research are to analyze the income of cocoa farming, the income of cocoa farmer households, the poverty level of cocoa farmer households, the factors affecting the poverty rate of cocoa farmer households. This research was conducted in Sungai Langka Village, Gedong Tataan Subdistrict Pesawaran Regency. Respondents were 51 cocoa farmers taken using stratified random sampling method based on land area. The analytical methods used were farm income analysis, household income analysis, household poverty level analysis, logistic analysis of farming household poverty level. The results showed that cash income of cocoa farming is Rp8,027,576.78 per ha per year and revenue at total cost Rp Rp4,335,373.38 per ha per year. The household income of cocoa farmers is Rp21,277,833.33 per year. Based on the World Bank indicator, the number of nonpoor farmers is 52.94 percent and poor farmers is 47.05 percent. And based on indicator BPS (2016) there are no poor farmers in food poverty, whereas the number of poor farmers in nonfood poverty is 31.37 percent and nonpoor farmers of 68.63 percent. The common poverty line is 21.57 percent of poor farmers and 78.43 percent of non-poor farmers. The percentage of the poor is 0.21 , the poverty intencity index is 0.042 , the poverty severity index is 0.00034 . Factors that affect the poverty level is household income.
\end{abstract}

Key words: cocoa, farming income, household income, poverty rate

\section{PENDAHULUAN}

Sektor pertanian merupakan sektor yang sangat penting dalam struktur perekonomian negara. Sektor pertanian menyumbang 14 persen dari PDB, memberdayakan sekitar 40 juta hektar lahan pertanian (Badan Pusat Statistik, 2015). Dalam tatanan global, Indonesia merupakan produsen utama kelapa sawit, produsen terbesar ke dua karet dan kakao, serta satu dari lima produsen utama kopi di dunia (Leimona dkk. 2015).

Provinsi Lampung adalah salah satu provinsi di wilayah Indonesia yang pendapatan penduduknya bergantung pada hasil dari alam. Salah satu sektor pertanian yang berperan utama dalam proses pembangunan di Provinsi Lampung adalah sub sektor perkebunan. Provinsi Lampung memiliki beberapa komoditas perkebunan yang diunggulkan, baik yang berasal dari perkebunan rakyat, perkebunan besar negara, maupun perkebunan besar swasta. Komoditas kakao merupakan salah satu komoditas perkebunan yang menjadi andalan bagi Provinsi Lampung yang memiliki luas areal tanaman menghasilkan sebesar 32.057 ha dengan produksi sebesar 28.067 ton.
Salah satu daerah di Provinsi Lampung yang menjadi andalan dalam produksi komoditas kakao adalah Kabupaten Pesawaran. Kabupaten Tanggamus memiliki produksi kakao tertinggi pertama di Provinsi Lampung namun produktivitas kakao di Tanggamus lebih rendah dibandingkan Kabupaten Pesawaran yang hanya menempati posisi ke tiga penghasil kakao di Provinsi Lampung. Kabupaten Lampung Timur dengan luas areal dan produksi kakao yang tinggi namun produktivitasnya lebih rendah dibandingkan dengan Kabupaten Pesawaran. Kabupaten Lampung Selatan dengan produktivitas kakao yang tinggi namun luas areal dan produksinya jauh lebih rendah dibandingkan dengan tiga sentra produksi kakao lainnya di Provinsi Lampung.

Kecamatan Gedong Tataan merupakan salah satu sentra produksi kakao di Kabupaten Pesawaran. Produksi kakao di Kecamatan Gedong Tataan di sokong oleh beberapa desa yang memiliki usahatani kakao. Salah satu desa di Kecamataan Gedong Tataan yang memproduksi kakao terbesar dibandingkan dengan desa lainnya adalah Desa Sungai Langka dengan produksi tanaman menghasilkan sebesar 925 ton dengan 
produktivitas sebesar 0,974 ton per ha. Tingginya produksi dan produktivitas petani kakao di Desa Sungai Langka diharapkan sejalan dengan besarnya tingkat pendapatan petani karena pendapatan petani merupakan salah satu faktor yang mempengaruhi tingkat kemiskinan petani.

Tingginya produksi dan produktivitas kakao di Desa Sungai Langka pada kenyataannya masih belum mampu menjadikan masyakaratnya bebas dari kemiskinan. Hal ini dapat dilihat dari masih banyaknya masyarakat miskin di Desa Sungai Langka yaitu sebanyak 425 keluarga. Menurut Kementerian Pedesaan Desa Sungai Langka merupakan salah satu desa yang termasuk dalam kategori tertinggal dan masih perlu banyak perbaikan. Di sisi lain Desa Sungai Langka memiliki banyak sekali potensi yang dapat menunjang kehidupan masyarakatnya. Penelitian ini betujuan untuk menganalisis: tingkat pendapatan usahatani kakao, tingkat pendapatan rumah tangga petani kakao dan tingkat kemiskinan rumah tangga petani kakao serta faktor-faktor yang mempengaruhi tingkat kemiskinan rumah tangga petani kakao.

\section{METODE PENELITIAN}

Penelitian ini menggunakan metode survei. Metode survei menurut Singarimbun dan Effendi (1995) adalah penelitian yang mengambil sampel dari suatu populasi dan menggunakan kuesioner sebagai alat pengumpulan data yang pokok. Penelitian dilakukan di Desa Sungai Langka Kecamatan Gedong Tataan Kabupaten Pesawaran. Pemilihan lokasi tersebut dilakukan secara sengaja (purposive) dengan pertimbangan bahwa desa tersebut merupakan sentra produksi kakao di Kecamataan Gedong Tataan karena memiliki produksi terbesar yaitu 925 ton pada tahun 2014 (Badan Pusat Statistik Kabupaten Pesawaran 2015b).

Jenis data yang digunakan dalam penelitian ini adalah data primer dan data sekunder. Data primer diperoleh dari wawancara secara langsung menggunakan kuesioner. Data sekunder berupa literatur terkait penelitian yang diperoleh dari Badan Pusat Statistik, laporan-laporan dan pustaka lainnya yang berkaitan dengan penelitian ini. Pengambilan data dilakukan pada bulan Desember 2016. Menurut hasil pra survei yang dilakukan populasi petani kakao di Desa Sungai Langka berjumlah 964 petani. Responden petani dipilih menggunakan metode stratified random sampling.
Penentuan jumlah sampel menggunakan rumus Isaac dan Michael (1995):

$$
\mathrm{n}=\frac{\mathrm{NZ}{ }^{2} \sigma^{2}}{\mathrm{~N} \delta^{2}+\mathrm{Z}^{2} \sigma}
$$

Keterangan :

$\mathrm{n}=$ Ukuran sampel

$\mathrm{N}=$ Ukuran petani kakao (964)

$\mathrm{Z} \quad=$ Derajat kepercayaan $\mathrm{Z}(90 \%=1,645)$

$\sigma^{2} \quad=$ Varian sampel $(5 \%=0,05)$

$\delta^{2}=$ Standar deviasi $(5 \%=0,05)$

Berdasarkan rumus tersebut ditentukan jumlah responden sebanyak 51 orang. Penentuan sampel dilakukan berdasarkan proporsi luas lahan yang dimiliki petani yang dibagi menjadi tiga strata yaitu lahan sempit, lahan sedang dan lahan luas. Penentuan alokasi proporsi sampel tiap strata luas lahan dirumuskan:

$\mathrm{n}_{\mathrm{a}}=\frac{\mathrm{N}_{\mathrm{a}} \mathrm{Xn}_{\mathrm{ab}}}{\mathrm{N}_{\mathrm{ab}}}$.

Keterangan:

$\mathrm{n}_{\mathrm{a}} \quad=$ Jumlah sampel per strata

$\mathrm{n}_{\mathrm{ab}} \quad=$ Jumlah sampel keseluruhan

$\mathrm{N}_{\mathrm{a}} \quad=$ Jumlah petani per strata

$\mathrm{N}_{\mathrm{ab}} \quad$ = Jumlah populasi keseluruhan

Berdasarkan perhitungan strata luas lahan di dapatkan sampel petani kakao untuk setiap strata adalah 40 rumah tangga untuk petani lahan sempit $(0,25-1,50)$ ha, delapan rumah tangga lahan sedang $(1,51-2,75)$ ha dan tiga rumah tangga lahan luas $(2,76-4,00)$ ha. Metode analisis data yang digunakan dalam penelitian ini adalah analisis deskriptif kualitatif dan kuantitatif.

Pendapatan usahatani diperoleh dengan menghitung selisih antara penerimaan yang diterima dari hasil usahatani dengan biaya produksi yang dikeluarkan dalam satu tahun. Pendapatan petani kakao dihitung dengan menggunakan rumus Soekartawi (1995):

$\pi=\mathrm{YP}_{\mathrm{y}^{-}} \sum \mathrm{X}_{\mathrm{i}} \mathrm{P}_{\mathrm{xi}}-\mathrm{BTT}$ 
$\mathrm{X}_{\mathrm{i}} \quad=$ Faktor produksi, $\mathrm{i}=1,2,3,4 \ldots \ldots, \mathrm{n}$

$\mathrm{Px}_{\mathrm{i}} \quad=$ Harga faktor produksi

BTT = Biaya tetap total

\section{Analisis Pendapatan Rumah Tangga}

Pendapatan diperoleh dengan menghitung selisih antara total penerimaan yang diterima dari hasil usaha dengan biaya produksi yang dikeluarkan selama satu tahun terakhir. Untuk mengetahui pendapatan rumah tangga petani digunakan rumus Rahim dan Hastuti (2008).

$$
\begin{aligned}
& \text { Prt } \left.=P_{\text {onfarm }} \text { (usahatani kakao }\right)+ \\
& \mathrm{P}_{\text {onfarm }} \text { (usahatani non kakao) + } \\
& \mathrm{P}_{\text {off farm }}+\mathrm{P}
\end{aligned}
$$

Keterangan:

$$
\begin{aligned}
& \text { Prt }=\text { Pendapatan rumah tangga } \\
& \text { petani kakao pertahun } \\
& \mathrm{P}_{\text {on farm (usahatani kakao) }}=\text { Pendapatan usahatani kakao } \\
& \mathrm{P}_{\text {on farm (nonkakao) }}=\text { Pendapatan usahatani non } \\
& \mathrm{P}_{\text {off farm }} \quad=\text { Pendapatan non usahatani } \\
& \mathrm{P}_{\text {nonfarm }} \quad=\text { Pendapatan dari luar }
\end{aligned}
$$

\section{Analisis Tingkat Kemiskinan Rumah Tangga}

Metode analisis untuk mengukur tingkat kemiskinan rumah tangga digunakan analisis kualitatif dengan menggunakan indikator Bank Dunia dan Badan Pusat Statistik (2016). Bank Dunia menetapkan garis kemiskinan sebesar U\$ 1 per kapita per hari artinya yang dianggap miskin di dunia, di negara manapun individu tersebut berada adalah yang memiliki pendapatan kurang dari U\$ 1 per kapita per hari, sedangkan menurut Badan Pusat Statistik (2016) kemiskinan adalah ketidakmampuan memenuhi standar minimum kebutuhan dasar dengan membandingkannya terhadap garis kemiskinan. Garis kemiskinan Provinsi Lampung September 2016 sebesar Rp392.488/kapita/bulan (Badan Pusat Statistik, 2016). Garis Kemiskinan (GK) yang terdiri dari dua komponen, yaitu garis kemiskinan makanan (GKM) yang merupakan nilai pengeluaran kebutuhan minimum makanan dengan garis kemiskinan bukan makanan (GKBM).

Garis kemiskinan makanan adalah nilai pengeluaran kebutuhan minimum makanan yang disetarakan dengan 2.100 kilo kalori per kapita per hari, dalam satuan rupiah (Rp/kapita/bulan). Garis kemiskinan makanan di Provinsi Lampung pada
September 2016 sebesar Rp279.240/kapita/bulan (Badan Pusat Statistik 2016). Garis Kemiskinan Bukan Makanan (GKBM) adalah kebutuhan minimum untuk perumahan, sandang, pendidikan dan kesehatan. Paket komoditi kebutuhan dasar non makanan diwakili oleh 51 jenis komoditi di perkotaan dan 47 jenis komoditi di pedesaan. Garis kemiskinan bukan makanan di Provinsi Lampung pada September 2016 sebesar Rp113.248/kapita/bulan (BPS 2016).

Tingkat kemiskinan dapat dirumuskan :

$\mathrm{GK}=\mathrm{GKM}+\mathrm{GKBM}$

Keterangan:

GK = Garis Kemiskinan

GKM = Garis Kemiskinan Makanan

GKBM $=$ Garis Kemiskinan Bukan Makan

Badan Pusat Statistik dalam mengukur kemiskinan selain dengan menggunakan pendekatan pemenuhan kebutuhan dasar juga mengukur kemiskinan dengan melihat persentase penduduk miskin, indeks kedalaman kemiskinan dan indeks keparahan kemiskinan untuk melihat seberapa besar tingkat kemiskinan di suatu masyarakat. Persentase penduduk miskin adalah persentase penduduk yang berada di bawah garis kemiskinan.

Persentase penduduk miskin dirumuskan:

$\mathrm{P}_{0}=\frac{1}{\mathrm{n}} \sum_{\mathrm{i}=1}^{\mathrm{q}}\left[\frac{\mathrm{Z}-\mathrm{yi}}{\mathrm{Z}}\right] \mathrm{a}$

Keterangan:

$\mathrm{a}=0$

$\mathrm{P}_{0}=$ Persentase penduduk miskin

$\mathrm{z}=$ Garis kemiskinan

yi = Rata-rata pengeluaran per kapita penduduk yang berada di bawah garis kemiskinan $(\mathrm{i}=1,2,3, \ldots . \mathrm{q}) ; \mathrm{yi}<\mathrm{z}$

$\mathrm{q}$ = Banyaknya penduduk yang berada di bawah garis kemiskinan

$\mathrm{n}$ = Jumlah penduduk (Badan Pusat Statistik 2016)

Indeks kedalaman kemiskinan (Poverty Gap Index$P 1)$ adalah ukuran rata-rata kesenjangan pengeluaran masing-masing penduduk miskin terhadap garis kemiskinan. Indeks kedalaman kemiskinan dirumuskan:

$\mathrm{P}_{\mathrm{a}}=\frac{1}{\mathrm{n}} \sum_{\mathrm{i}=1}^{\mathrm{q}}\left[\frac{\mathrm{Z}-\mathrm{yi}}{\mathrm{Z}}\right] \mathrm{a}$ 
Keterangan:

$$
\begin{aligned}
\mathrm{a}= & 1 \\
\mathrm{P}_{1}= & \text { Indeks kedalaman kemiskinan } \\
\mathrm{z}= & \text { Garis kemiskinan } \\
\mathrm{yi}= & \text { Rata-rata pengeluaran per kapita penduduk } \\
& \text { yang berada di bawah garis kemiskinan } \\
& (\mathrm{i}=1,2,3, \ldots . . \mathrm{q}) ; \text { yi }<\mathrm{z} \\
\mathrm{q}= & \text { Banyaknya penduduk yang berada di bawah } \\
& \text { garis kemiskinan } \\
\mathrm{n}= & \text { Jumlah penduduk (Badan Pusat Statistik } \\
& \text { 2016) }
\end{aligned}
$$

Indeks keparahan kemiskinan (Proverty Severity Index-P2) adalah gambaran mengenai penyebaran pengeluaran diantara penduduk miskin. Indeks keparahan kemiskinan dirumuskan:

$$
\mathrm{P}_{\mathrm{a}}=\frac{1}{\mathrm{n}} \sum_{\mathrm{i}=1}^{\mathrm{q}}\left[\frac{\mathrm{Z}-\mathrm{yi}}{\mathrm{Z}}\right] \mathrm{a}
$$

Keterangan:

$\mathrm{a}=2$

$\mathrm{P}_{2}=$ Indeks keparahan kemiskinan

$\mathrm{z}=$ Garis kemiskinan

yi $=$ Rata-rata pengeluaran per kapita penduduk yang berada di bawah garis kemiskinan $(\mathrm{i}=1,2,3, \ldots . \mathrm{q})$; $\mathrm{yi}<\mathrm{z}$

$\mathrm{q}=$ Banyaknya penduduk yang berada di bawah garis kemiskinan

$\mathrm{n}=$ Jumlah penduduk (Badan Pusat Statistik 2016)

\section{Analisis Faktor- faktor yang Mempengaruhi Tingkat Kemiskinan}

Metode yang digunakan untuk mengetahui faktorfaktor yang mempengaruhi tingkat kemiskinan rumah tangga dengan menggunakan analisis logistik dengan rumus :

$\mathrm{Zi}=\beta_{0}+\beta_{1} \mathrm{X}_{1}+\beta_{2} \mathrm{X}_{2}+\beta_{3} \mathrm{X}_{3}+\beta_{4} \mathrm{X}_{4}+\beta_{5} \mathrm{X}_{5}+\beta_{6} \mathrm{X}_{6}+\beta_{7} \mathrm{D}+\mathrm{e}$
Keterangan:

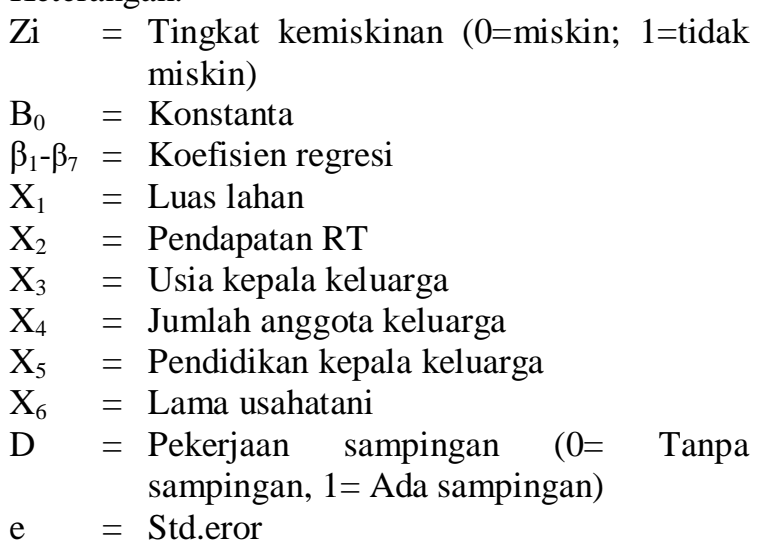

\section{HASIL DAN PEMBAHASAN}

Mayoritas petani kakao rata-rata berada pada kisaran umur 30-34 dengan persentase 47,06 persen. Jika dilihat dari tingkat pendidikan petani kakao maka tingkatan tertinggi berada pada tingkat pendidikan SMP sebesar 21 orang $(41,18 \%)$. Jumlah anggota keluarga terdiri dari 1 sampai 6 orang. Jumlah anggota keluarga petani kakao tertinggi berada pada kisaran 4-5 orang dengan persentase 66,67 persen. Petani kakao memiliki luas lahan rata-rata $0,25-1,50$ ha sebanyak 78,43 persen. Pengalaman usahatani 10-16 tahun merupakan persentase tertinggi yaitu 54,90 persen. Pekerjaan sampingan petani berupa pedagang sayuran, pengumpul, buruh pertanian/non pertanian, pegawai swasta, jasa angkutan, pengrajin hasil pertanian, beternak, warung/toko klontong, dan pegawai kelurahan.

\section{Pendapatan Usahatani Kakao}

Produksi kakao di Desa Sungai Langka terbagi menjadi produksi pada masa panen biasa dan masa panen raya. Panen biasa memiliki produksi lebih rendah dibandingkan dengan panen raya. Produksi kakao saat panen biasa diperoleh sebesar 230,10 $\mathrm{kg}$, sedangkan produksi saat panen raya sebesar $374,61 \mathrm{~kg}$. Biaya produksi dalam usahatani kakao meliputi biaya pupuk, biaya pestisida, biaya tenaga kerja luar keluarga, biaya iuran kelompok, biaya pajak, biaya iuran jalan. Penerimaan, biaya usahatani dan pendapatan kakao di Desa Sungai Langka, 2016 disajikan pada Tabel 1. 


\section{JIIA, VOLUME 6, No. 1, FEBRUARI 2018}

Tabel 1. Penerimaan, biaya, dan pendapatan usahatani kakao di Desa Sungai Langka, 2016

\begin{tabular}{|c|c|c|c|c|c|}
\hline \multirow[b]{2}{*}{ No } & \multirow[b]{2}{*}{ Uraian } & \multirow[b]{2}{*}{ Satuan } & \multicolumn{3}{|c|}{ Per 1,3 ha } \\
\hline & & & Jumlah & Harga $(\mathrm{Rp})$ & Nilai (Rp) \\
\hline \multirow[t]{4}{*}{1.} & Penerimaan & & & & \\
\hline & Produksi Panen Raya & $\mathrm{Kg}$ & 374,61 & $18.960,78$ & $7.200 .588,24$ \\
\hline & Produksi Non Panen Raya & $\mathrm{Kg}$ & 230,10 & $15.882,35$ & $3.701 .960,78$ \\
\hline & & & & & $10.902 .549,02$ \\
\hline \multirow[t]{24}{*}{2.} & A. Biaya Tunai & $\mathrm{Kg}$ & & & \\
\hline & - Pupuk Urea & $\mathrm{Kg}$ & 135,29 & $1.262,75$ & $279.803,92$ \\
\hline & - Pupuk Phonska & $\mathrm{Kg}$ & 74,61 & $1.552,94$ & $191.078,43$ \\
\hline & - Pupuk Dolomit & $\mathrm{Kg}$ & 32,25 & 278,00 & $18.627,45$ \\
\hline & - Pupuk Kandang & $\mathrm{Kg}$ & 470,59 & 42,75 & $79.607,84$ \\
\hline & - Pupuk NPK & $\mathrm{Kg}$ & & & \\
\hline & - Mutiara & & 1,37 & 235,29 & $16.470,59$ \\
\hline & - Ziolit & $\mathrm{Kg}$ & 22,94 & 225,49 & $26.862,75$ \\
\hline & - Pupuk KCl & $\mathrm{Rp}$ & 1,08 & 715,69 & $13.137,25$ \\
\hline & - Pestisida & $\mathrm{Rp}$ & & & $155.578,43$ \\
\hline & - Iuran Kelompok & $\mathrm{Rp}$ & & & $10.196,07$ \\
\hline & - Pajak & $\mathrm{Rp}$ & & & $77.745,09$ \\
\hline & - Iuran Jalan & $\mathrm{Rp}$ & & & $48.137,25$ \\
\hline & - TK Luar & $\mathrm{Rp}$ & & & \\
\hline & - Keluarga & & & & $914.142,16$ \\
\hline & - Total Biaya Tunai & $\mathrm{Rp}$ & & & $1.831 .387,25$ \\
\hline & B. Biaya Diperhitungkan & $\mathrm{Rp}$ & & & \\
\hline & - TK Dalam & $\mathrm{Rp}$ & & & \\
\hline & - Keluarga & & & & $1.111 .066,18$ \\
\hline & - Sewa Lahan & $\mathrm{Rp}$ & & & $1.884 .313,73$ \\
\hline & - Pupuk Kandang & $\mathrm{Rp}$ & & & $888.745,098$ \\
\hline & - Penyusutan Alat & $\mathrm{Rp}$ & & & $288.064,8459$ \\
\hline & - Total Biaya Diperhitungkan & & & & $4.172 .189,85$ \\
\hline & C. Total Biaya & & & & $6.003 .577,10$ \\
\hline 3. & Pendapatan Atas Biaya Tunai & $\mathrm{Rp}$ & & & $9.071 .161,76$ \\
\hline 4. & Pendapatan Atas Biaya Total & & & & 4.898.971,92 \\
\hline
\end{tabular}

Penerimaan yang diperoleh petani kakao dari hasil usahatani kakao pada rata-rata luas lahan 1,13 ha adalah sebesar Rp10.902.549,02 atau Rp9.648.273,47 per ha. Hasil ini lebih kecil dibanding dengan penelitian yang dilakukan Gusti, Haryono, Prasmatiwi (2013) yang menyatakan bahwa penerimaan yang diperoleh petani dari hasil usahatani kakao di daerah penelitian sebesar Rp15.651.473,28 per ha.

Penerimaan kakao di Desa Sungai Langka lebih rendah disebabkan produksi usahatani yang rendah karena faktor hama dan penyakit tanaman yang menyerang usahatani kakao dan faktor umur ekonomis kakao yang sudah tidak produktif. Pendapatan atas biaya tunai yang diperoleh petani kakao di Desa Sungai Langka selama satu tahun terakhir sebesar Rp8.027.576,78 per ha, sedangkan pendapatan atas biaya total usahatani kakao di Desa Sungai Langka sebesar Rp4.335.373,38 yang dikategorikan sangat tinggi menurut Badan Pusat Statistik tahun 2008.

\section{Pendapatan Rumah Tangga Petani Kakao}

Pendapatan rumah tangga petani diperoleh dari berbagai usaha yang dilakukan petani. Petani kakao di daerah penelitian memperoleh pendapatannya dari sektor on farm kakao, tumpangsari tanaman kakao (karet, cabai, pisang, cengkeh, durian, petai, alpukat, kelapa) dan ternak, off farm (pedagang hasil pertanian, penggarap lahan pertanian, kerajinan pertanian) dan non farm (pensiunan, PNS/POLRI, dagang, usaha angkutan).

Pendapatan petani kakao terbanyak diperoleh dari pendapatan on farm baik dari usahatani kakao dan tumpangsari maupun usaha ternak. Hal ini terjadi karena usahatani merupakan pendapatan utama petani di Desa Sungai Langka. Rata-rata pendapatan rumah tangga petani di Desa Sungai Langka sebesar Rp21.277.833,33. Pendapatan on farm kakao menyumbang sekitar 86,61 persen dari pendapatan rumah tangga petani kakao. Hal ini menunjukkan bahwa sektor pertanian merupakan penyumbang terbesar pendapatan petani kakao. Usaha non farm menyumbang rata-rata pendapatan rumah tangga petani kakao terbesar kedua yaitu sekitar 9,92 persen dari pendapatan rumah tangga 
petani kakao. Hal ini terjadi karena pendapatan yang diperoleh dari usaha non pertanian setiap tahunnya cukup besar. Pendapatan dari off farm hanya memberikan kontribusi sebesar 3,47 persen dari total pendapatan rumah tangga petani kakao.

Hal ini sejalan dengan penelitian Iqbal, Lestari, Soelaiman (2013) sumber pendapatan dari usahatani ubi kayu memiliki kontribusi terbesar yaitu Rp24.463.926,76 kemudian yang ke dua yaitu sumber pendapatan non pertanian Rp1.972.849,46 dan selanjutnya sumber pendapatan yang ke tiga yaitu sumber pendapatan non ubi kayu Rp328.125,00 karena usahatani on farm merupakan sumber utama pendapatan rumah tangga petani. Hasil penelitian Iqbal, Lestari, Soelaiman (2013) menunjukkan pendapatan usahatani ubi kayu yang diperoleh lebih besar dibandingkan dengan pendapatan usahatani kakao yang diperoleh di Desa Sungai Langka selama setahun terakhir. Hal ini disebabkan oleh beberapa faktor yaitu faktor umur tanaman kakao yang sudah tidak produktif lagi dan faktor hama penyakit tanaman yang saat ini menyerang tanaman kakao. Struktur pendapatan rumah tangga petani kakao di Desa Sungai Langka disajikan pada Tabel 2.

\section{Kemiskinan Rumah Tangga Petani Kakao}

Rata-rata pendapatan per kapita petani di Desa Sungai Langka menurut Bank Dunia Rp 14.059,95 per kapita per hari. Berdasarkan indikator Bank Dunia terdapat 27 orang petani yang tidak miskin dengan persentase sebesar 52,94 persen dan 24 orang petani yang masuk dalam kategori miskin dengan persentase sebesar 47,05 persen. Petani yang masuk dalam kategori miskin diperoleh dengan membandingkan pendapatan per kapita per hari dengan standar Bank Dunia yaitu U\$ 1 atau setara dengan nilai tukar rupiah sebesar Rp13,325.00. Sebaran petani berdasarkan tingkat kemiskinan Bank Dunia di sajikan pada Tabel 3.

Rata-rata pengeluaran petani di Desa Sungai Langka menurut Badan Pusat Statistik Rp1.235.999,69 per bulan. Indikator Badan Pusat Statistik (2016) tidak terdapat petani yang miskin pada kemiskinan makanan, sedangkan pada kemiskinan bukan makanan terdapat 31,37 persen petani yang miskin dan 68,63 persen petani yang tidak miskin. Kemiskinan secara umum terdapat 21,57 persen petani yang miskin dan 78,43 persen petani yang tidak miskin. Sebaran petani kakao berdasarkan tingkat kemiskinan indikator Badan Pusat Statistik 2016 pada Tabel 4.
Presentase petani kakao miskin di Desa Sungai Langka sebesar 0,2156. Persentase penduduk miskin yang tinggi menunjukan bahwa tingkat kemiskinan disuatu wilayah tinggi. Indeks kedalaman. kemiskinan di Desa Sungai Langka diperoleh sebesar 0,0008. Hal ini menujukkan ketimpangan pengeluaran di antara penduduk miskin sebesar 0,0008. Nilai indeks keparahan kemiskinan sebesar 0,0003 artinya terdapat variasi pengeluran penduduk miskin sebesar 0,0003.

Tabel 2. Struktur pendapatan rumah tangga petani kakao di Desa Sungai Langka

\begin{tabular}{llrr}
\hline No & $\begin{array}{c}\text { Jenis Sumber } \\
\text { Pendapatan }\end{array}$ & $\begin{array}{c}\text { Rata-Rata } \\
\text { Pendapatan (Rp) }\end{array}$ & $\begin{array}{c}\text { Kontribusi } \\
\text { Perhadap } \\
\text { Pendapatan } \\
\text { Rumah tangga } \\
(\%)\end{array}$ \\
\hline 1. & $\begin{array}{l}\text { On } \\
\text { farm(Kakao, } \\
\text { tumpangsari } \\
\text { kakao dan } \\
\text { ternak) }\end{array}$ & $21.277 .833,3$ & 86,61 \\
2. & Off farm & $852.941,1$ & 3,47 \\
3. & Non farm & $2.437 .254,90$ & 9,92 \\
\hline & Total & $24.568 .029,4$ & 100,0 \\
\hline
\end{tabular}

Tabel 3. Sebaran tingkat kemiskinan petani berdasarkan indikator Bank Dunia di Desa Sungai Langka

\begin{tabular}{|c|c|c|c|}
\hline No & Kategori & Jumlah (Orang) & $\begin{array}{c}\text { Persentase } \\
(\%)\end{array}$ \\
\hline 1. & $\begin{array}{l}\text { Tidak } \\
\text { Miskin }>1 \$\end{array}$ & 27 & 52,94 \\
\hline 2. & Miskin $<1 \$$ & 24 & 47,05 \\
\hline & Jumlah & 51 & 51 \\
\hline
\end{tabular}

Tabel 4. Sebaran tingkat kemiskinan petani berdasarkan indikator Badan Pusat Statistik 2016 di Desa Sungai Langka

\begin{tabular}{lccc}
\hline & \multicolumn{3}{c}{ Garis Kemiskinan } \\
\cline { 2 - 4 } Kategori & $\begin{array}{c}\text { Makanan } \\
(\%)\end{array}$ & $\begin{array}{c}\text { Bukan } \\
\text { Makanan } \\
(\%)\end{array}$ & $\begin{array}{c}\text { Makanan+Bukan } \\
\text { Makanan }(\%)\end{array}$ \\
\hline $\begin{array}{l}\text { Miskin } \\
\text { Tidak }\end{array}$ & 0 & 31,37 & 21,57 \\
Miskin & 100 & 68,63 & 78,43 \\
\hline $\begin{array}{l}\text { Keterangan: } \\
\text { GKM }=\text { Rp279.240 }\end{array}$ & & \\
GKBM & $=$ Rp113.248 & & \\
GK $\quad=$ Rp392.488 & &
\end{tabular}


Tabel 5. Hasil uji anallogistik faktor-faktor yang mempengaruhi tingkat kemiskinan rumah tangga petani di Desa Sungai Langka

\begin{tabular}{crrrr}
\hline \multicolumn{5}{c}{ Dependent Variable: Y } \\
\hline Variable & Coefficient & Std. Error & Z-Statistic & Prob. \\
\hline C & -10.24922 & 5.020599 & -2.041433 & 0.0412 \\
X1 & 1.366619 & 1.351151 & 1.011448 & 0.3118 \\
X2 & $\mathbf{3 . 4 6 E - 0 7}$ & $\mathbf{1 . 2 9 E - 0 7}$ & $\mathbf{2 . 6 8 0 1 4 9}$ & $\mathbf{0 . 0 0 7 4}$ \\
X3 & 0.056483 & 0.073623 & 0.767189 & 0.4430 \\
X4 & 0.378054 & 0.594344 & 0.636087 & 0.5247 \\
X5 & 0.173625 & 0.241353 & 0.719380 & 0.4719 \\
X6 & 0.023277 & 0.166498 & 0.139804 & 0.8888 \\
D & -0.136906 & 1.363083 & -0.100438 & 0.9200 \\
\hline McFadden R-squared & & 0.585786 & \\
\hline LR statistic & & 31.15338 & \\
Prob(LR statistic) & & & \\
\hline Keterangan: & & & \\
$\mathrm{X}_{1}=$ Luas lahan & & & \\
$\mathrm{X}_{2}=$ Pendapatan rumah tangga & & & \\
$\mathrm{X}_{3}=$ Usia kepala keluarga & & & \\
$\mathrm{X}_{4}=$ Jumlah anggota keluarga & & & \\
$\mathrm{X}_{5}=$ Tingkat pendidikan KK & & & \\
$\mathrm{X}_{6}=$ Lama usahatani & & & & \\
D = Pekerjaan sampingan & &
\end{tabular}

Faktor-faktor yang Mempengaruhi Kemiskinan Rumah Tangga

Metode yang digunakan dalam mengukur faktorfaktor yang mempengaruhi tingkat kemiskinan rumah tangga petani kakao di Desa Sungai Langka dengan menggunakan analisis logistik. Faktor pendapatan rumah tangga petani kakao berpengaruh positif terhadap tingkat kemiskinan artinya semakin tinggi pendapatan petani maka semakin jauh dari kemiskinan. Tingkat pendidikan, luas lahan, lama usahatani, jumlah anggota keluarga, usia kepala keluarga dan pekerjaan sampingan tidak berpengaruh nyata. Hasil penelitian ini sedikit berbeda dengan penelitian Puji, Sumaryo, dan Dewangga (2014) yaitu faktor yang berpengaruh nyata terhadap tingkat kesejahteraan adalah luas lahan dan tingkat pendidikan.

Nilai LR statistik diperoleh sebesar 31,15 dengan tingkat kepercayaan sebesar 99 persen artinya secara bersama-sama variabel pendapatan rumah tangga berpengaruh nyata terhadap tingkat kemiskinan rumah tangga dengan taraf kepercayaan sebesar 99 persen. Nilai Rsquare diperoleh sebesar 0,58 artinya 58 persen tingkat kemiskinan dapat dijelaskan oleh variabel luas lahan, pendapatan rumah tangga, usia KK, jumlah anggota keluarga, tingkat pendidikan KK, lama usahatani, pekerjaaan sampingan, sedangkan sisanya sebesar 0,42 persen dijelaskan oleh variabel-variabel lain yang tidak dimasukkan ke dalam model. Nilai odd ratio pendapatan rumah tangga diperoleh sebesar 1,00 artinya setiap peningkatan variabel pendapatan rumah tangga sebesar satu satuan akan meningkatkan peluang tingkat kemiskinan sebesar 1,00 satuan.

\section{KESIMPULAN}

Pendapatan usahatani kakao di Desa Sungai Langka Kecamatan Gedong Tataan Kabupaten Pesawaran selama satu tahun terakhir masuk dalam kategori sangat tinggi. Petani kakao di Desa Sungai Langka memperoleh pendapatan rumah tangga sebesar Rp21.277.833,33 per tahun. Berdasarkan indikator Bank Dunia dan Badan Pusat Statistik jumlah petani yang masuk dalam kategori tidak miskin lebih besar dibandingkan dengan petani yang masuk dalam kategori miskin. Persentase penduduk miskin cukup besar. Nilai indeks kedalaman kemiskinan di Desa Sungai Langka cukup besar sedangkan nilai indeks keparahan kemiskinan di Desa Sungai Langka cukup besar. Pendapatan rumah tangga berpengaruh positif terhadap tingkat kemiskinan rumah tangga.

\section{DAFTAR PUSTAKA}

Badan Pusat Statistik Jakarta. Golongan Pendapatan. Badan Pusat Statistik Jakarta. Jakarta.

Badan Pusat Statistik. 2016. Istilah Kemiskinan. Badan Pusat Statistik Provinsi Lampung. Bandar Lampung.

Badan Pusat Statistik Provinsi Lampung. 2015. Lampung Dalam Angka. Badan Pusat Statistik Provinsi Lampung. Bandar Lampung.

Badan Pusat Statistik Kabupaten Pesawaran. 2015a. Pesawaran Dalam Angka. Badan Pusat Statistik Kabupaten Pesawaran. Pesawaran.

Badan Pusat Statistik Kabupaten Pesawaran. 2015b. Pesawaran Dalam Angka. Badan Pusat Statistik Kabupaten Pesawaran. Pesawaran.

Dinas Perkebunan Provinsi Lampung. 2015. Luas Areal dan Produksi Tanaman Perkebunan Rakyat, Perkebunan Besar Negara Perkebunan Besar Swasta di Provinsi Lampung. Dinas Perkebunan Provinsi Lampung. Bandar Lampung.

Direktorat Jendral Perkebunan. 2014. Statistik Perkebunan Indonesia. Direktorat Jendral Perkebunan. Jakarta. 
Gusti JIK, D Haryono, dan FE Prasmatiwi. 2013. Pendapatan rumah tangga petani kakao di Desa Pesawaran Indah Kecamatan Padang Cermin Kabupaten Pesawaran. Jurnal IlmuIlmu Agrbisnis: 1(4). 278-283. [8 Oktober 2016]

Iqbal AM, DAH Lestari, dan A Soelaiman. 2013. Pendapatan dan kesejahteraan rumah tangga petani ubi kayu di Kecamatan Sukadana Kabupaten Lampung Timur. Jurnal Ilmu-Ilmu Agribisnis:2(3): 246-252. [8 Oktober 2016]

Isaac S dan Michael WB. 1995. Handbook in research and evaluation. San Diego. Edits.

Leimona B, Sacha A, Bustanul A, Fitria Y, Fadhil H, Herdhata A, Peter S, Steven J, dan Jaime F. 2015. Kebijakan dan Strategi "Pertanian
Hijau Indonesia": Menjembatani Antara Kesejangan Aspirasi dan Aplikasi.Word Agroforestry Center (ICRAFT). Bogor.

Puji PU, Sumaryo Gs, dan Dewangga N. Pendapatan dan kesejahteraan petani jagung di Ketapang Kabupaten Lampung Selatan. Jurnal Ilmu-Ilmu Agribisnis: 4(3): 25-26. [26 Februari 2017]

Rahim ABD dan DRD Hastuti. 2008. Ekonomika Pertanian (Pengantar Teori dan Kasus). Penebar Swadaya. Jakarta.

Singarimbun M dan Effendi S. 1995. Metode Penelitian Survei. Edisi Revisi. PT Pustaka LP3ES. Jakarta.

Soekartawi. 1995. Analisis Usahatani. UI-Press. Jakarta. 